ECPS Leader Profile Series \#5

February 2021

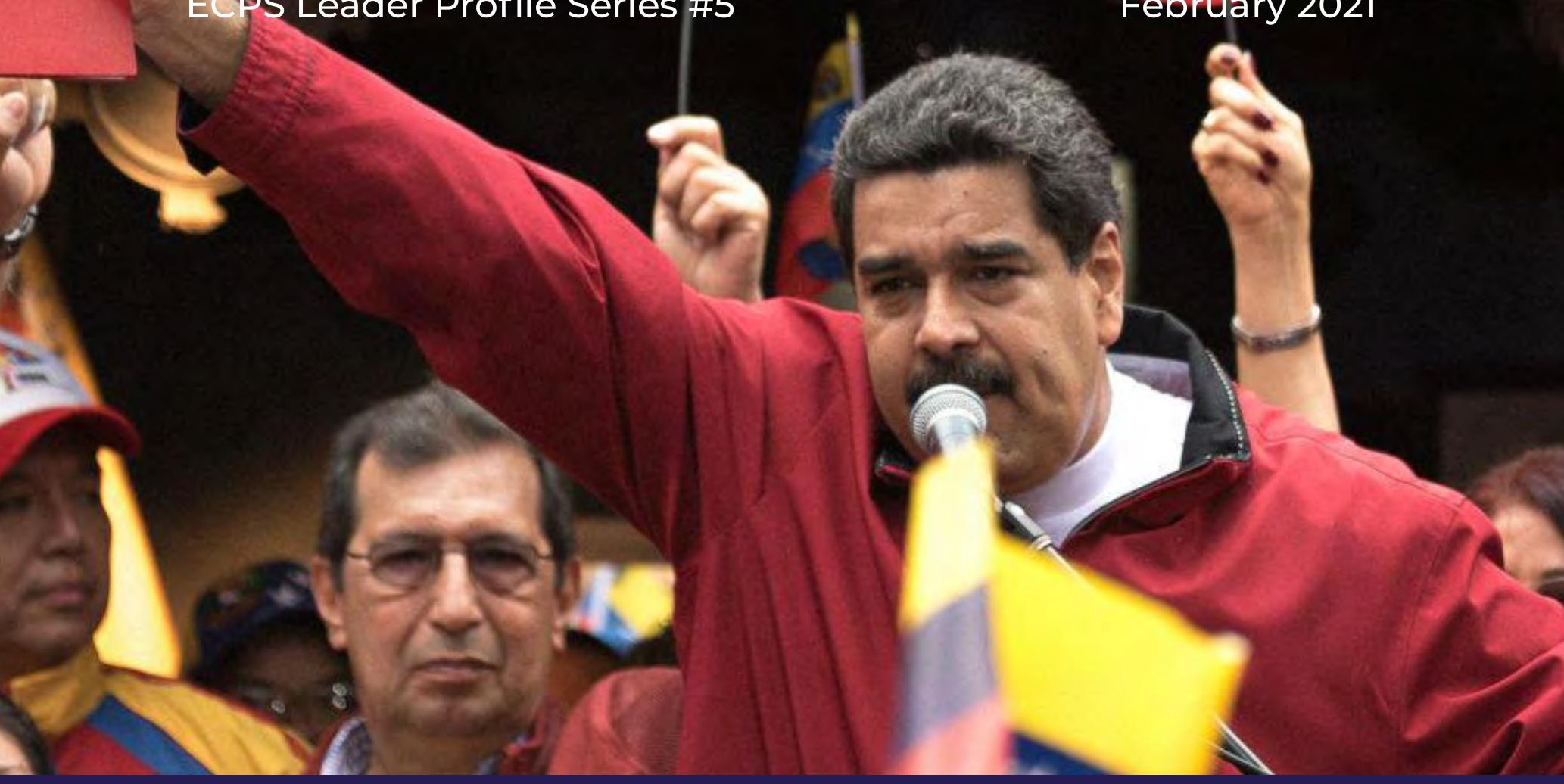

AUTHOR: Imdat Oner

\title{
Nicolas Maduro: A populist without popularity
}

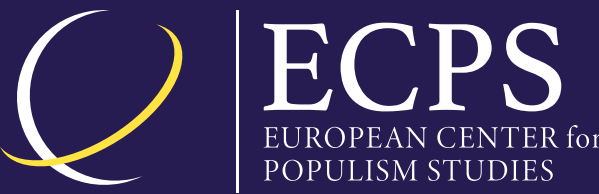




\section{Nicolas Maduro: A populist without popularity}

BY IMDAT ONER

\section{ABSTRACT}

Lacking personal charisma and booming oil revenues, Nicolas Maduro of Venezuela has struggled to obtain his predecessor's popular support and failed to legitimize his rule at the polls. Instead, Maduro consolidated his power through sharing it with elites and the military. Externally, the country's social, economic, and political environment has contributed to the growing perception among international actors that the regime is becoming ever more authoritarian and unstable. In the face of the greatest threat to its survival both at home and abroad, Maduro and his allies eliminated Venezuela's remaining democratic institutions.

The Maduro administration remains reluctant to make any concessions that might erode its power. With implicit and explicit power-sharing arrangements with key actors at the domestic level, Maduro has been able to cling to power. Currently, the military still supports Maduro; there are no signs this will change anytime soon. As the recent political events suggest, and barring free and fair elections, unpopular populist Maduro will remain in power.

IMDAT ONER is a Senior Policy Analyst at Jack D. Gordon Institute. He is currently a Ph.D. candidate in International Relations at Florida International University.

ECPS Leader Profile Series offer analyses of political leaders and prominent public figures with populist tendencies. Unless otherwise indicated, the views expressed by the author are only attributable him and not to any institution with which they are associated.

The profile available for free downloading from the ECPS website (wwW. populismstudies.org)

(C) ECPS 2021 


\section{Table of contents}

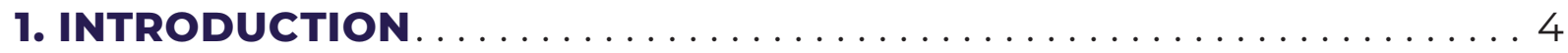

2. MADURO'S BACKGROUND $\ldots \ldots \ldots \ldots \ldots \ldots \ldots \ldots \ldots \ldots \ldots$

3. IS MADURO A POPULIST LEADER? $\ldots \ldots \ldots \ldots \ldots \ldots \ldots \ldots \ldots$

4. NEW AUTHORITARIANISM UNDER AN UNPOPULAR POPULIST

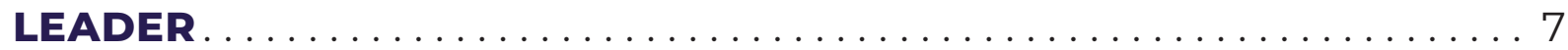

5. THE ALLIANCE WITH THE MILITARY $\ldots \ldots \ldots \ldots \ldots \ldots \ldots$

6. FALL OF THE PETRO-STATE UNDER THE MADURO ADMINISTRATION .................................... 11

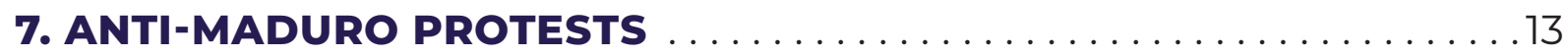

8. MADURO'S PRESIDENCY FACING QUESTIONS OF LEGITIMACY. . . .14

9. ANOTHER POPULIST PLAYBOOK: FOREIGN PLOTS

10. AN AUTHORITARIAN COALITION WITH LIKE-MINDED REGIMES . . 17

CONCLUSION 


\section{INTRODUCTION}

Latin America has long been a fertile political landscape for populist leaders. Argentina's Eva Peron, Peru's Victor Raúl Haya de la Torre, Brazil's Getulio Vargas, and Ecuador's José María Velasco Ibarra are all well-known populist leaders. For these politicians, populism was a viable political strategy, one they used to mobilize people against the "elites" on their way to obtaining and retaining power. Claiming to be the embodiment of the "pure" people, Latin American populists have rejected checks and balances that would limit their power, which they view as derived from the people's will.

A second wave of populism has taken root throughout Latin America with the rise of Hugo Chávez in Venezuela, Evo Morales in Bolivia, Kirshner in Argentina, and Rafael Correa in Ecuador. They mainly rose to power amid the rising sentiment against neoliberal policies. Adopting an anti-American discourse and anti-neoliberal approach, these pink-tide leaders have continued the region's populist tradition. Like their predecessors, these new populist leaders appeal to the excluded masses by mobilizing against the establishment and promising better lives for their supporters.

The rise of Chávez in Venezuela has especially inspired academic studies of populism, which is known as one of Latin America's most enduring political traditions. Elected on the promise of ending neoliberal economic policies and corrupt politicians, the late President Chávez ruled Venezuela from 1999 to 2013. His movement, Chavismo, drew heavily on the charismatic populist connection between his leadership and the people. While he was planning to remain in power until 2021 (La Tercera, 2008), he passed away at the age of 58 after a long battle with cancer. Following his death in 2013, Nicolas Maduro - in full, Nicolás Maduro Moros - came to power as Chávez's handpicked successor. Maduro, Vice President under Chávez, was sworn-in in April 2013 as Venezuela's interim President until new elections could be held. He inherited the leadership of the United Socialist Party of Venezuela (Partido Socialista Unido de Venezuela; PSUV) and announced he would be the party's candidate for the upcoming presidential elections.

Designated by Chávez as his political heir, Maduro narrowly won the election. Despite a less favourable international situation and complex domestic socio-economic conditions, Maduro committed himself and his regime to further authoritarianism, to solidify his hold on power. Under his administration, Venezuela has been an emblematic case of severe democratic erosion while suffering a major economic and humanitarian crisis. This paper will seek to introduce a detailed profile of Maduro and his place within the region's populist politics. 


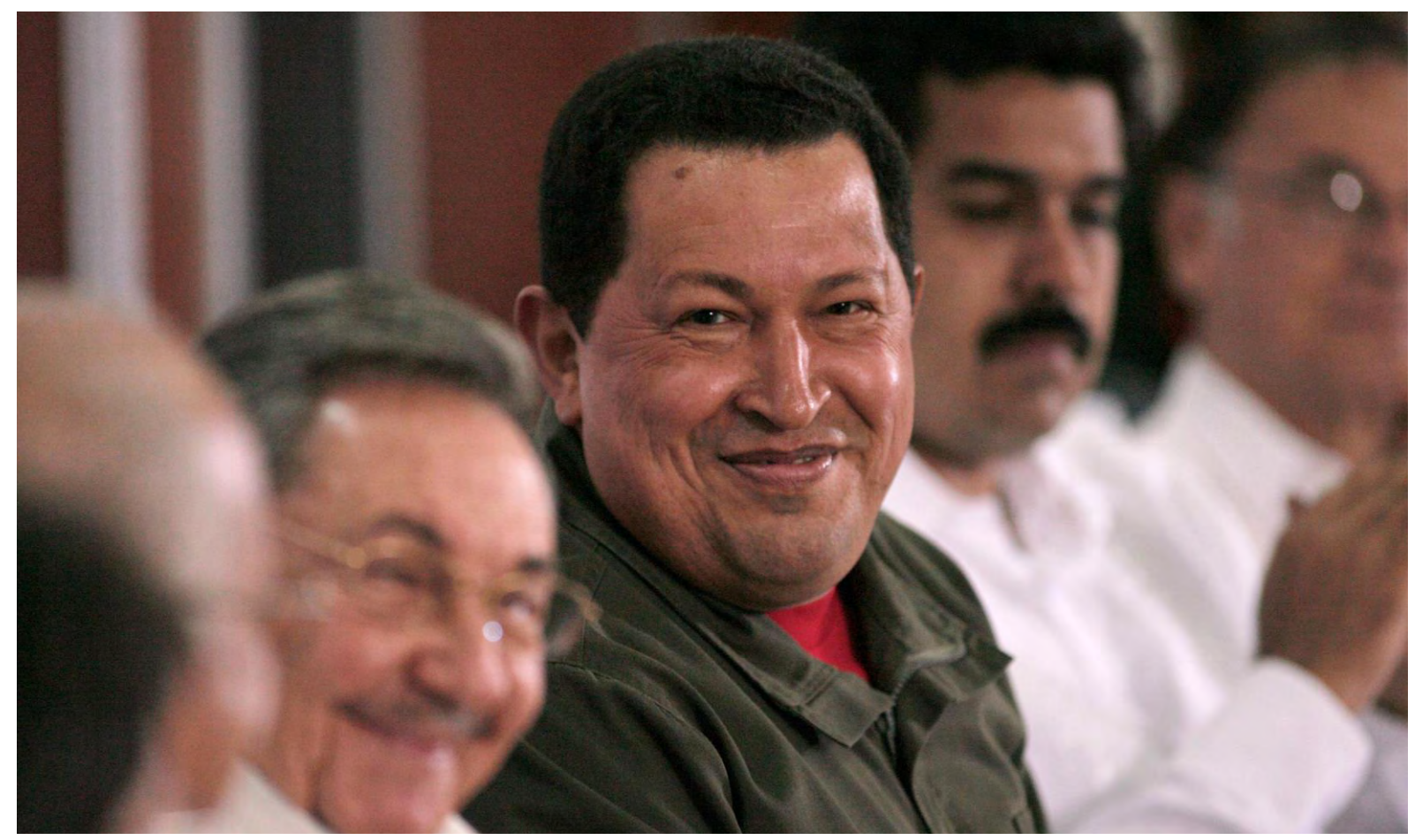

The former presidents of Cuba, Raul Castro (L) and of Venezuela, Hugo Chavez (C) and Nicolas Maduro (R) in Cumana, Venezuela on April 17, 2009.

\section{Maduro's \\ Background}

Born in 1962 into a family that had heavily engaged in leftist politics and labour movements, Maduro followed his parents' footsteps and began his political life in the student union during his high school years (The Guardian, 2013). His educational career is murky. Several records indicate that he could not finish high school (Cola, 2018). The most well-known fact about Maduro's early age is that he worked as a bus driver. In those years, Maduro was actively attending labour union activities. He got involved in politics through leftist groups such as Rupture and the Socialist League (Dobson, 2018). At 24, Maduro moved to Cuba and attended a one-year course at the Escuela Nacional de Cuadros Julio Antonio Mella, a political training centre run by the Union of Young Communists (Oropeza, 2013). He trained to become a professional revolutionary (Naim and Toro, 2018). His connection with Cuba at this young age would later play a critical role in his regime's survival.

Maduro was long part of Chávez's inner circle. His first connection with Chávez dates to the early 1990s. Maduro participated in the 1992 military coup against President Carlos Andrés Pérez, which was led by Chávez (Oropeza, 2013).After the failed attempt, Chávez was sent to a military prison; Maduro campaigned for his release (The Guardian, 2013).Maduro's wife, Cilia Flores, led the legal team that worked to get Chávez freed. Since the beginning, Maduro and his family were among Chávez's most faithful supporters. Maduro's strong ties to Chavismo and Chávez have been critical factors advancing his political career. Maduro slowly but surely climbed the political career ladder.

Maduro's strong ties to Chavismo and Chávez have been critical factors advancing his political career. Maduro slowly but surely climbed the political career ladder. First, he took an active role in founding the Fifth Republic Movement, initiated by Chávez ahead of the 1998 elections. After Chávez's successful rise to power in 1998, Maduro became part of the Constituent Assembly, which drafted the new Venezuelan constitution. Then, he served a long string as a deputy at Parliament. He was re-elected in the 2005 parliamentary elections and became the President of the National Assembly. One year later, Chávez appointed him Minister of Foreign Affairs. The former bus driver 
was the longest-serving minister at this post during Chávez's reign (Alarcon Deza, 2014). In 2012, shortly after Chávez's victory in the presidential election, Maduro became Vice President. Before leaving for surgery in Cuba in December 2012, Chávez picked his long-time loyal confidant as his successor. In his last public appearance, President Chávez described Maduro as "a complete revolutionary, a man of great experience despite his youth, with great dedication and capacity for work, for leading, for handling the most difficult situations" (Chuck, 2017).

\section{Is Maduro A Populist Leader?}

Jan-Verner Mueller (2013) has raised a critical question: "Can populism thrive without a genuinely popular and charismatic leader?" It is generally accepted that populist leaders derive their legitimacy and authority from the people and their popular support. Claiming to have the people's support, populists believe in popular sovereignty as manifested by regular elections and referenda representing the people's will. Put simply, this has never been the case for Maduro. First of all, Maduro was appointed by Chávez as his successor. While carrying out his role as interim president, he ran for office in special elections convened in April 2013, in the wake of Chávez's death. Maduro had neither Chávez's charisma nor his support. Calling himself "the son of Chávez," Maduro narrowly won the election against opposition leader Henrique Capriles by a mere 1.5 percent. Compared to other populist leaders, he has grown deeply unpopular since his election.

Lacking Chávez's charisma, Maduro has been unable to enjoy the level of popular support Chávez did. Shortly after he assumed office, his job approval suffered amid rising economic problems, including hyperinflation, devaluation, and rampant poverty. Among the populace, there was a growing distrust of the Maduro government. According to Corrales and Bergen (2016), there was no single indicator of governance that improved under Maduro, and he was perceived as the weak-

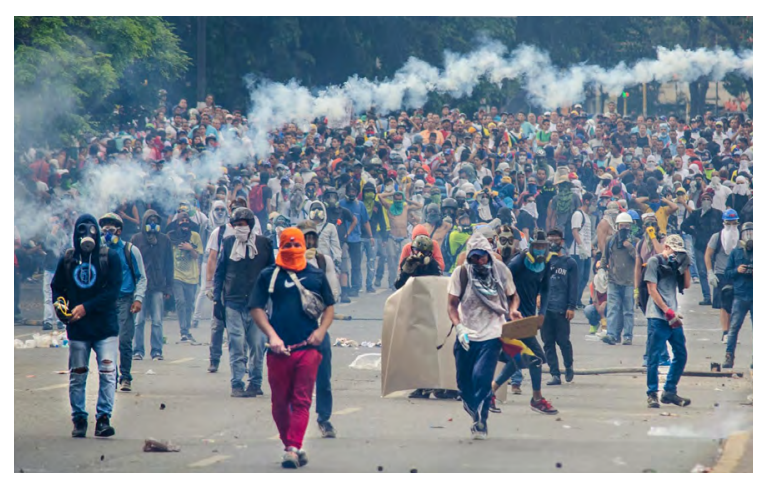

The members of the Venezuelan resistance protested against the Maduro government in Caracas, Venezuela on April 26, 2017.

est president in Venezuelan history. The existing problems pointed to significant losses for Maduro and his party in upcoming elections. Reliable polling indicated that Maduro's approval rating stood below 25 percent before the end of 2014, and around two-thirds of the country believed that he would not be able to complete his first presidential term (Reuters, 2014). These numbers make more sense when put in context and compared to his predecessor's approval ratings. Since Chávez first came to power in 1999, his party, The United Socialist Party of Venezuela (Partido Socialista Unido de Venezuela, PSUV), has dominated Venezuelan politics. During the Chávez era, PSUV won every election, both presidential and parliamentary. And remarkably, Chávez won his last election, in 2012, by 11 points and enjoyed a 57 percent approval rating just before he died (Corrales and Bergen, 2016).

Maduro's low approval rating suggests he lacks a unique feature of populist leaders: charismatic appeal. As Carlos de la Torre has written, in hyper-personalistic regimes, charisma cannot be transferred to a handpicked successor (De la Torre, 2017). As Maduro lacks personal charisma, he constantly invokes Chávez's memory and legacy to capitalize on the latter's genuine popularity among the people. Before he was elected in 2013, Maduro overwhelmingly relied on his predecessor's political capital and legitimacy to gain the people's support. Maduro and party followers strongly endorsed the slogan of "Chávez lives! The struggle continues! Always fighting for victory, Comandante!" (Angosto-Ferrández, 2016). Although Maduro sought to emulate Chávez's tactics and style, his fierce rhet- 
oric without strong charisma failed to galvanize Chávez's electoral base.

Maduro's low approval rating became more evident in the 2015 parliamentary elections. The electoral coalition of the opposition parties, called Mesa de Unidad Democrática, (Democratic Unity Table MUD), won a landslide victory against the ruling party PSUV. The result was a record 74 percent turnout, with 58 percent of voters supporting the opposition and only 42 percent supporting the government (Neuman, 2015). PSUV lost control of the assembly for the first time since Chávez came to power in 1999. The opposition achieved a three-fifths majority, which enabled them to pass laws, censure, and remove government ministers and the executive vice president.

Despite lacking charisma, Maduro has displayed one classic trait of populism, by framing Venezuela's struggle as the "pure" people against the oligarchs. A recent study from the Global Populism Discourse, which identifies populist discourse in the speeches of world leaders, labels Maduro as "very populist" on the basis of speech analysis (Lewis et al., 2019). Like his predecessor Chávez, Maduro's discourse permanently seeks to divide society into two separate groups and explicitly articulates an existential struggle between them. The discourse mostly revolves around confrontational rhetoric, framing politics as a zero-sum game between the people and the conspiring elite. Similar to other populist leaders, Maduro treats his political opponents not as competitors but "enemies of the homeland" to be defeated (Rodriguez-Garavito and Gomez 2018). Rhetorically, he portrays himself as a victim, even at the height of his power, blaming domestic or foreign elites. UItimately, the populist discourse aims at legitimizing the use of any means to stay in power.

The dismantling of Venezuelan democracy, which started under Chávez, was a long and gradual process. While Chávez used populism to entrench his power and consolidate a competitive authoritarian regime in the country, Maduro scaled up to full-blown authoritarianism in the face of eroding support for his government.

\section{New Authoritarian- ism Under an Un- popular Populist Leader}

Even though Maduro differs from other populist leaders in terms of lower popular support, he shares another commonality with them: posing a danger to liberal democracy (Hawkins and Ruth, 2016; Weyland, 2013). After inheriting a hybrid regime, Maduro followed a playbook left in place by his predecessor. The deepening socio-economic crisis and increasing domestic instability have increased pressure on Maduro. To maintain his power, he has become more radical, adopting authoritarian tactics on several fronts, including weakening state institutions, undermining checks and balances, polarizing society into two camps, and stacking the playing field against his opponents.

The dismantling of Venezuelan democracy, which started under Chávez, was a long and gradual process. During the Chávez era, Venezuela was governed by a semi-authoritarian regime, with extremely weak democratic institutions and skewed checks and balances. While Chávez used populism to entrench his power and consolidate a competitive authoritarian regime in the country (Corrales and Penfold, 2011; Levitsky and Loxton, 2012), Maduro scaled up to full-blown authoritarianism in the face of eroding support for his government. As a Freedom House (2017) report indicated, under the Maduro administration, Venezuela gradually transitioned from a "partly free" democracy into a "not free" authoritarian regime. As Maduro's support has waned at home, the executive branch increasingly engages in traditional authoritarian practices to consolidate political power and eliminate any efforts that would threaten its survival. Facing internal and external crises, the Maduro administration has adopted all sorts of repressive measures, including undermining state institutions, arresting opposition leaders, and suppressing the press (Corrales, 2015: 44). 
In this respect, the parliamentary elections in 2015 became a litmus test of whether the regime would accept losing any power through elections (Marsteintredet, 2020). Faced with a sweeping opposition victory, Maduro initially acknowledged the results by saying, "The bad guys won, like the bad guys always do, through lies and fraud" (The Guardian, 2015). But before long, the government implied that it had no intention of sharing its power with an opposition-led parliament. Within two years, the parliament was weakened, first by the electoral council's denial of the seats necessary for a supermajority, next by the Supreme Court's rejection of the authority of the legislative body, and finally by a constituent assembly that rules in the place of the National Assembly.

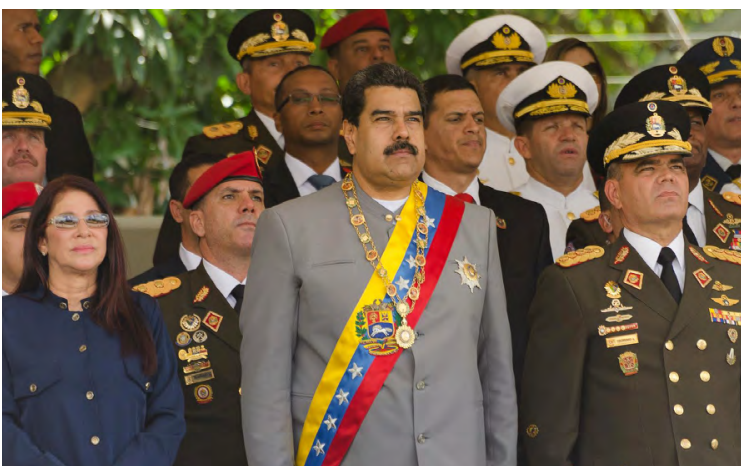

Nicolás Maduro with First Lady Cilia Flores and Defense Minister Vladimir Padrino López are seen as watching a military parade in Caracas on February 1 , 2017.

In the years following the 2015 elections, the country was riven by deep polarization and faced a political impasse, as Maduro felt more insecure about holding power. By early May 2016, the opposition had submitted petitions with some 1.8 million signatures to call for a referendum that would remove Maduro from power. Nevertheless, with the help of the National Electoral Council (CNE), which the government has filled with Maduro loyalists, the referendum was blocked. This manipulation was simply another confirmation that the ruling party would not accept the results of an election that it might lose.

Similarly, the Supreme Court repeatedly undermined the opposition-dominated National Assembly's authority as an equal branch of power, routinely overturning the laws that it enacted. The Court has been turned into a political weapon of the Maduro administration. Shortly after the opposition gained control of parliament in 2015, Maduro repacked the Court with unconditional loyalists by circumventing the judicial appointment procedures outlined in the constitution (Freeman, 2020). The Supreme Court nullified nearly all legislation that the National Assembly passed in 2016 and stripped it of its budgetary powers. Moreover, Maduro asked the Court for extraordinary powers to govern by decree, bypassing the legislative body's checks and balances.

Political interference in the judiciary is not new in Venezuela. This "judicial shield" was also used by Chávez, who packed the Court with his loyalists (Correa and Recinos 2016). Yet, the Supreme Court during the Maduro administration has become an arm of an authoritarian executive (IJC, 2017). A report by the International Commission of Jurists's (IJC) indicates that the executive has decisively co-opted the Court, whose members mainly consist of members of the ruling party and ex-government officials. For example, last year, the Supreme Court unilaterally appointed a new electoral commission, which was supposed to be appointed by parliament. Nevertheless, the Supreme Court argued that the opposition-run legislature was in "unconstitutional omission." The Court suspended the leadership of the two leading opposition parties (Primero Justicia and Acción Democrática) and appointed Maduro supporters to lead both parties instead. Finally, the Court increased the number of seats in the National Assembly from 166 to 277, a means of packing the legislature (Human Rights Watch, 2020).

While the CNE and the Supreme Court significantly curtailed the National Assembly's authority and ability to legislate, Maduro aimed to fully dissolve it in 2017. The government controversially created a new Constituent Assembly to supersede parliament's authority and bypass its legislation. Its alleged purpose was to draft a new constitution, yet it never happened. The Constituent Assembly assumed de facto power and made all the country's important political decisions, giving Maduro full control of the process. This explicitly marked Venezuela's exit from democracy. 
Under the Maduro administration, electoral irregularities have also become more common (Corrales, 2016). The regime understands that it cannot survive a free and fair election, especially after the resounding defeat in the 2015 parliamentary elections. Although the remine has inherited several "legacy" irregularities from Chávez, Maduro has also introduced new, election-specific irregularities of his own (Corrales, 2016). It is widely accepted that electoral conditions under Chávez were never free and fair, and the incumbent party enjoyed an uneven playing field, but the elections were more competitive and happened mostly on schedule (Corrales, 2016). During the Maduro administration, Venezuela has experienced significant electoral irregularities, including the abuse of state power to the incumbent's advantage, gerrymandered electoral districts, and public media access for opposition candidates (Alarcón, Álvarez, \& Hidalgo, 2016).The government's electoral strategy is designed to turn out its core supporters while discouraging its opponents from voting. Maduro has created an environment that enables the ruling party to hold elections without any risk of losing.

Meanwhile, the number of political prisoners has significantly increased under the authoritarian Maduro administration. Like other populist autocrats, Maduro has labelled the opposition leaders "traitors" serving as allies of foreign countries. Popular opposition members have been mostly side-lined from the political process, either through being jailed or forced to live in exile; some have been disqualified from holding office (Singer, 2019). The leader of the Popular Will Party, Leopoldo López, was one of the most popular opposition leaders; he was sentenced to almost 14 years in prison for a series of alleged crimes related to his participation in the protests of early 2014. Another popular opposition leader, Henrique Capriles, who has run twice as a presidential candidate, was barred by Maduro's government from running for office. The Supreme Court also lifted parliamentary immunity for Freddy Guevara, the National Assembly's vice president, who the government accused of crimes for his involvement in street protests (Semple, 2017).
As part of a larger authoritarian playbook, the political prisoners have also been used as a bargaining chip by the Maduro administration. For instance, in August 2020, the Venezuelan government pardoned more than 100 opposition politicians, including more than 20 legislators who had been accused of conspiring against the government (Reuters, 2010). Maduro attempted to use these prisoners as part of an ongoing negotiation ahead of parliamentary elections.

Amid diminishing government support, Maduro is increasingly bolstered by a loyal security apparatus, including the military and police. After losing Chávez's political capital amid the deteriorating economic situation, Maduro has leaned increasingly on the military, which has become vital to his regime's survival.

\section{The Alliance with the Military}

Chávez's main strategy was to use plebiscitarian mass support to transform established institutions and concentrate power in the hands of the President (Weyland, 2013). However, Maduro, unlike other populist leaders, lacks the charisma to appeal to popular support. Instead, he consolidated support among the Chavista's inner forces and the military (Romero and Mijares, 2016). Lopez Maya (2018) describes Maduro's government as a "neopatrimonial rule"; it is not a simple populist regime. According to her, Chávez's close circle coalesced around Maduro, letting him rule along with his family, friends, and the military. Maduro originally derived his legitimacy from those implicit domestic coalitions rather than the people's vote.

Amid diminishing government support, Maduro is increasingly bolstered by a loyal security apparatus, including the military and police. After losing Chávez's political capital amid the deteriorating economic situation, Maduro has leaned increasingly on the military, which has become vital to his regime's survival. Maduro and his allies understood that the military would be a decisive player in the political game. The lack of charismatic leadership and popular support has made a power-sharing ar- 
rangement with the military necessary.

It is important to note here that the high "militarization" of Venezuelan politics dates back to Chávez, who espoused a narrative of the "civil-military alliance" even in the early years of his administration (Strønen, 2016). A significant number of military officers entered into the traditionally civilian space of public offices, effectively militarizing the political system. While many military officers were purged during the Chávez era, some loyal officers were promoted to critical civilian posts.

With Maduro, the Venezuelan military has become even more involved in politics through a series of rewards granted by the government in accordance with implicit power-sharing arrangements. Maduro sought to shore up his support in the armed forces after the defeat in the parliamentary elections (Smilde, 2015). Losing a critical branch of power, Maduro rewarded "profit-seeking soldiers" with access to cabinet posts and the control of banks and other financial institutions (Correa, 2020). High-level bureaucratic cadres and political posts have been staffed with military officers. The officers have a massive presence in the presidential office, vice-ministries, and among governors, mostly without giving up their military offices. As of 2020 , eight members of Maduro's 33-member cabinet - and seven of the nineteen governors who belong to the ruling party - are active or retired military members (Correa, 2020). Several key sectors now rest in the hands of military officers, including the distribution of food and basic products. Maduro appointed Defence Minister General Vladimir Padrino López as head of the "Grand Supply Mission" in 2016, handing him control of Venezuela's entire food supply system. Since then, the Venezuelan army has become the main authority regulating food and medicine distribution across the country

Maduro has surrounded himself with a group that faces high exit costs if the ruling party loses power, thereby ensuring their support for his survival in office (Cannon and Brown, 2017). For example, David Smilde (2016) argues that Maduro has picked generals for his inner circle who are on the US blacklist for drug trafficking or human rights violations. Theseindividuals have much to lose in any political transition favouring democracy and the rule of law. Any transition to democracy could lead to prosecution and long-term imprisonment. High ranking military officials are expected to remain loyal to their commander-in-chief, since their ability to avoid justice depends on Maduro's survival.

Maduro has needed to consolidate support amongst the military: since he came to power, the likelihood of a coup has increased. Fed up with rampant corruption, rapid democratic backsliding, and the dire economic situation, some factions of the opposition considered the possibility of a military intervention. Maduro, in fact, claims there have been several attempted coups against his government (Lansberg-Rodríguez, 2015). Some Venezuelan opposition members and generals were arrested by intelligence agents and indicted on charges of conspiracy against the government. According to Corrales (2020), by mid-2019, the Maduro administration held 217 active and retired military officers in prison, many of them without trial. While the Venezuelan government fingered opposition members, generals, and businesspeople as plotting a "coup" against Maduro, he also accused the United States of masterminding an attempt to overthrow him.

The army has played a significant role in supporting Maduro's legitimacy and power, especially at critical turning points. The military's support of Maduro smoothed the way for his consolidation of power. That support has not been uniform, however. In 2019, dozens of military members joined Juan Guaido's uprising attempt. However, none of them were upper-level military members, and the attempt failed. 


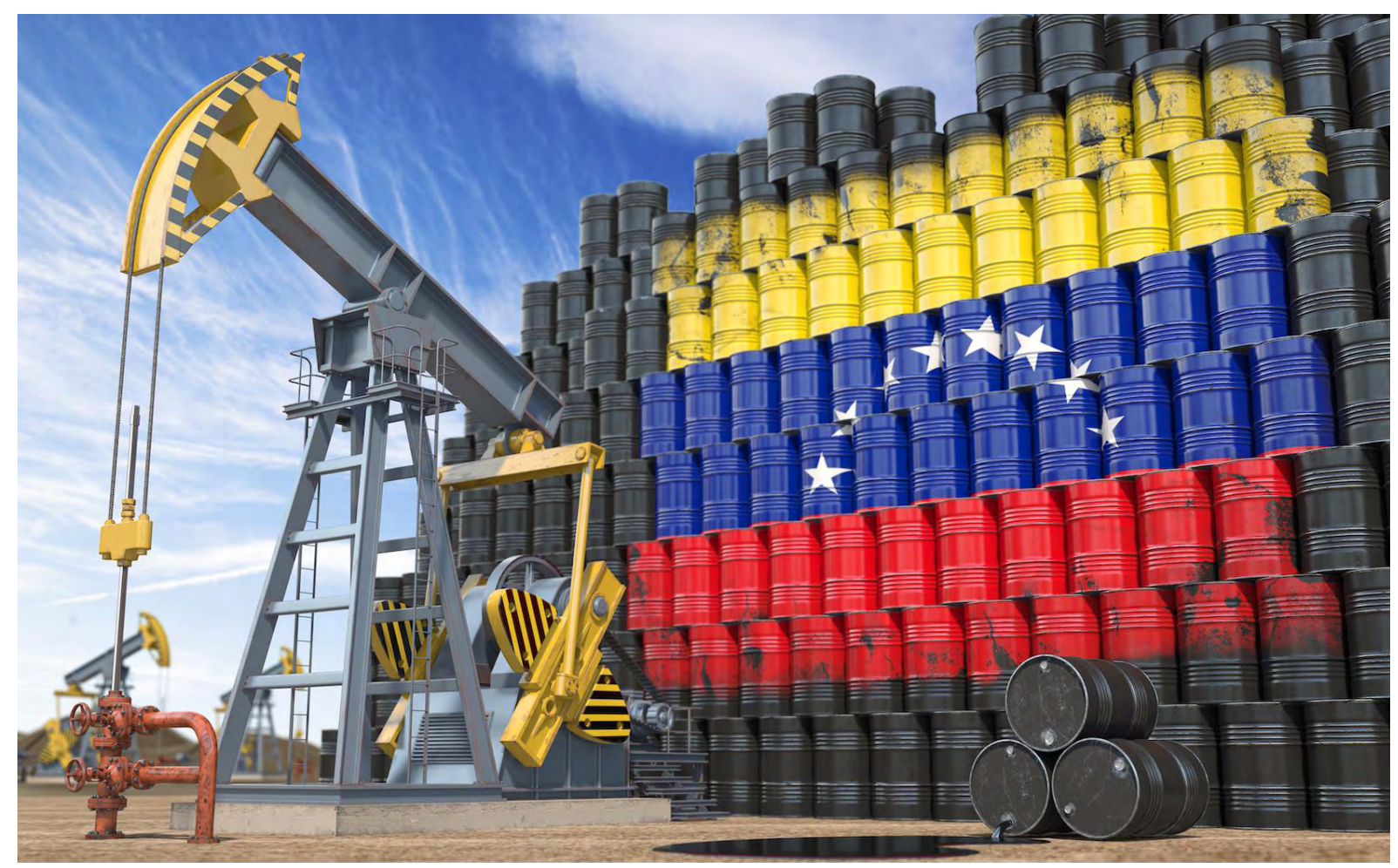

Oil pump jack and oil barrels with Venezuelan flag.

\section{Fall of the Petro-state Under the Maduro Administration}

Maduro also lacks another significant asset that Chávez enjoyed: booming oil prices. Oil accounts for around 90 percent of petro-state Venezuela's exports (OPEC, 2016). Instead of saving the oil revenue for the future, Chávez just funnelled booming oil revenue into social programs targeting the poor, including subsidized food, free healthcare, and education. Even though Chávez was a highly charismatic leader, his popularity also heavily depended on his government's economic performance and generous social programs funded by oil money, which in turn spurred the voters' support for him.

Maduro was elected president amid an unfavourable economic environment and would soon feel the long-term economic pain that Chávez wrought for the sake of short-term gain. Shortly after Maduro took office, the global price of petroleum crashed, triggering Venezuela's most serious economic and social crisis in recent history. Since 2013, the country has lost 62 percent of its Gross Domestic Product (GDP) (Bull and Rosales, 2020). The economic crisis has rapidly spiralled into a serious humanitarian crisis marked by worsening public services, malnutrition, and shortages, including for food and medicine.

Venezuelan oil production has also declined because of international sanctions and a lack of maintenance in the oil sector. Instead of market-friendly economic reforms and relaxing price controls, Maduro chose to continue with his predecessor's populist economic policies, including nationalizations, tight state control of the economy, and uncontrolled printing of money. Some short-term relief did not solve the complicated problems. Losing his popular support, Maduro was, indeed, not in a position to deviate from Chávez's socialist policies mainly due to a fear of losing his base (Smilde, 2015). Maduro's economic management was also marred by a series of incompetent appointments. At a critical time when the economic crisis deepened, Maduro appointed a professor who believed inflation does not really exist (Ellsworth, 2016).

The decline in state revenue due to 
the sharp fall in oil prices also resulted in reduced social welfare programs. As social programs benefiting the poor, the clientelist social networks providing services in exchange for political support has significantly expanded under Maduro's rule. Even though food distribution and other social programs have long been in place, at least since Chávez was in power, the massive misuse of state resources became more frequent through solid patronage and clientelist politics under the Maduro administration (Buxton, 2017). Maduro explicitly used government resources to guarantee his re-election for another term. For example, before the presidential elections in 2018, Maduro expanded food subsidies nationally to assure a high electoral turnout (Penfold, 2018). Under military control, food was used as a political tool to reward and mobilize supporters and punish opponents. The voters who were not ideologically aligned with Maduro were excluded from food distributions and other social programs (García-Guadilla and Mallen, 2019).

The neo-patrimonial rule under Maduro also allowed corruption and illicit businesses to flourish across the country. According to Transparency International (2019), Venezuela is among the most corrupt countries in the world (of a total of 180 countries included in the Corruption Perception Index, Venezuela ranks 169). A recent example of the complex corruption schemes initiated under Maduro's rule is the "Local Committees for Supply and Production (CLAP) program." Initially created to provide subsidized food to poor citizens, the program has turned into a complex corruption network that made money from overvalued contracts, which eventually enriched high-level officials (Reuters, 2019). While corruption has proliferated under Maduro's rule, other illicit businesses, including drug trafficking, have emerged as a key source of profits for the ruling elite (Naim and Toro, 2018). 


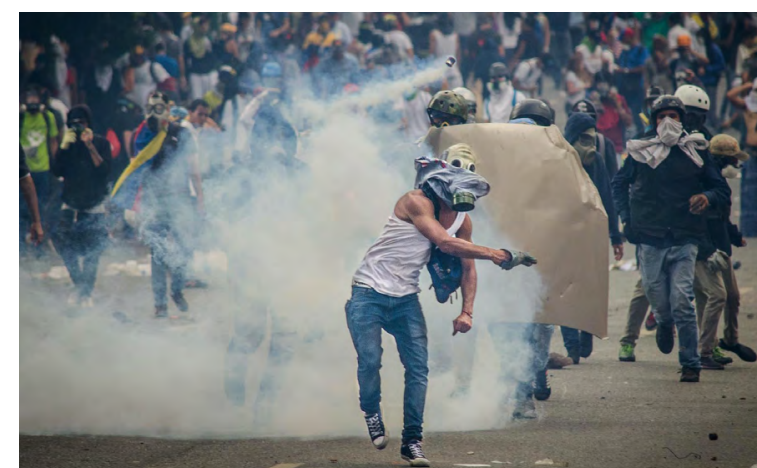

Opposition protested against the government of Nicolas Maduro in Caracas, Venezuela on April 26, 2017.

\section{Anti-Maduro Protests}

This difficult economic situation has been accompanied by a pronounced deterioration in social issues and, consequently, an increase in the levels of political conflict. Deteriorating economic conditions, economic mismanagement, and rampant corruption have undermined Maduro's unravelling support over the years, leading to widespread discontent among broad sectors of the population, even including some faction of Chávez supporters. Inevitably, the worsening situation triggered several massive protests across the country against rising repression, the high cost of living, and misgovernance.

Amid growing frustration, in 2014, the government faced the first massive demonstrations. Leopoldo López, an opposition leader, led national street protests in opposition to Maduro as part of a strategy known as "La Salida" (The Way Out). Hard-line members of the opposition and students took part. The demonstrations were severely repressed by Venezuelan security forces, resulting in the deaths of 43 people.

The country witnessed another set of widespread protests in 2017, when the Supreme Court stripped the opposition-led parliament's legislative powers. This decision prompted widespread outrage in the country. A month of huge protests against Maduro's rule involved instances of looting and violence. Maduro reacted to these protesters by referring to them as "vandals and terrorists" and called his supporters to the streets (Romo and Marilia, 2017). Similarly, he ramped up his fierce rhetoric against the right-wing opposition and external powers.

Maduro violently cracked down on the protests and imprisoned his major political rivals. Security forces repeatedly used excessive force to repress anti-government demonstrations, resulting in dozens of deaths. Several international institutions documented human rights violations committed by state authorities. Recently, a UN Human Rights Council fact-finding mission identified findings about extrajudicial executions, enforced disappearances, arbitrary detentions, and torture committed in the country since 2014 (UN Human Rights Council, 2020). Similarly, the International Criminal Court's (ICC) prosecutor reported that there is a "reasonable basis" to believe Venezuelan civilian authorities, members of the armed forces, and pro-government individuals had committed crimes against humanity (Reuters, 2020) 


\section{Maduro's Presidency Facing Questions of Legitimacy}

Under conditions significantly favouring the incumbent party - including voting irregularities - the main opposition parties decided to boycott the next presidential (2018) and parliamentary elections (2020), saying the electoral system was rigged in favour of Maduro and his party.

In May 2018, the presidential elections took place amid criticism of domestic and international actors. Maduro was re-elected with 67 percent of the vote, although only 46 percent of eligible voters participated. The high abstention rate was due to the opposition's boycott.The election was rejected and labelled illegitimate by several countries and international organizations, including the United States, the Lima Group (12 of 13 Latin American member countries and Canada), and the European Union.

In January 2019, Maduro was sworn in for his second term as president amid questions about his legitimacy. Only two weeks after Maduro's swearing-in ceremony, the President of the National Assembly and the opposition leader Juan Guaido declared himself the country's acting President. His claim rested on a provision in the 1999 constitution that allows the president of parliament to assume power temporarily in the absence of a president-elect. The opposition argued that Maduro had not been elected legally, and, therefore, the country was without a president. Since 2019, Venezuela has been caught in a political conflict between the two men who claim to be its rightful president.

\section{Even though Guaido was recognized} as President by more than 50 countries, he has remained powerless and struggled to gain control. Most critically, he did not succeed in persuading the upper echelons of the military - the most critical power player in Maduro's survival - to turn against the regime. With Maduro firmly entrenched in power, Guaido-led efforts have failed to change the political dynamic on the ground. In June 2020, ruling-party lawmakers elected one of the opposition members backed by Maduro to lead the parliament, depriving Guaidó

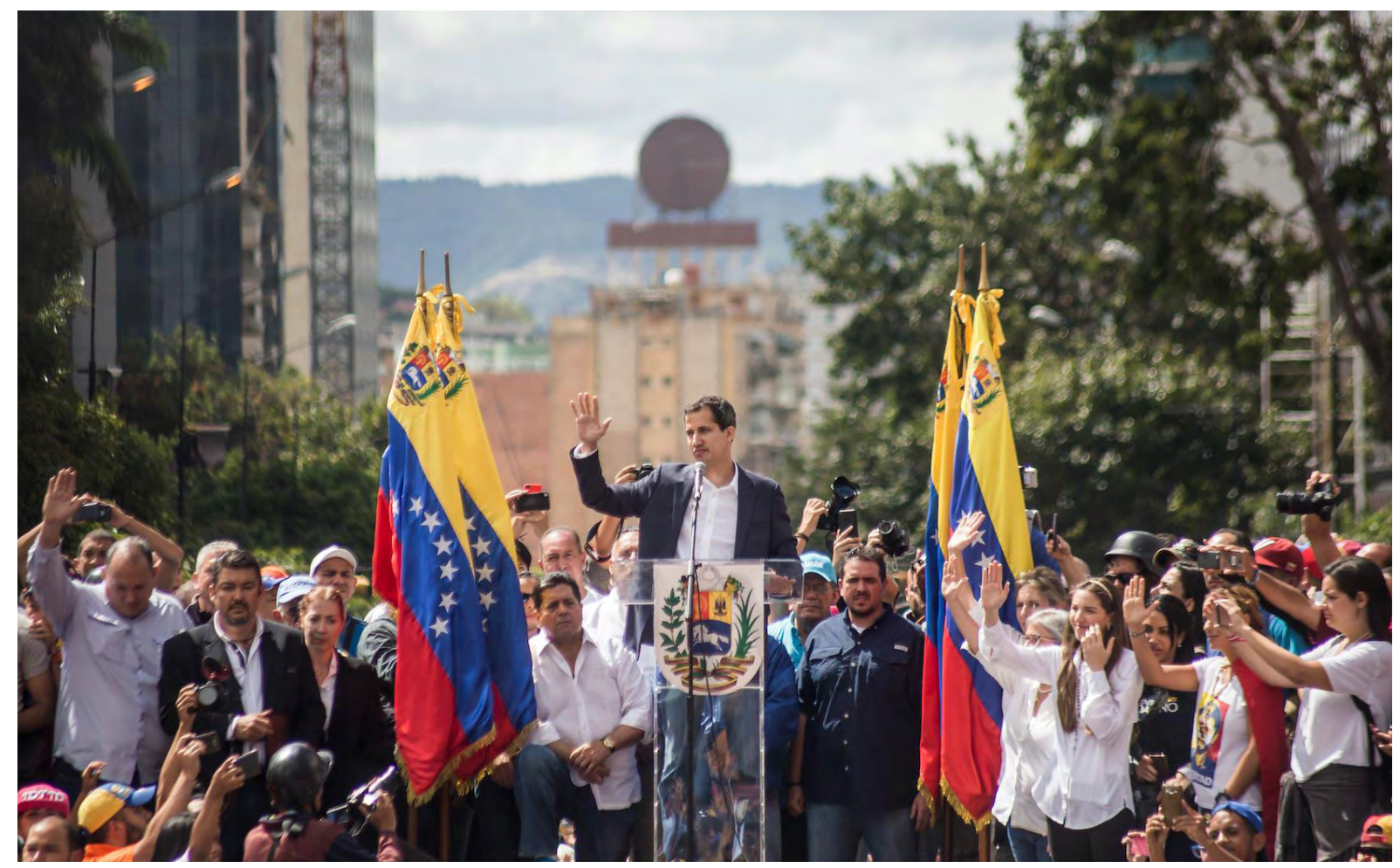

President of Venezuelan National Assembly Juan Guaido talks to the people during a rally in Caracas, Venezuela on January 23, 2019 
of his position (Krygier and Faiola, 2020). While the opposition declared this move a "parliamentary coup," Guaido's popularity significantly declined only one year after he promised to remove Maduro from power.

Seeking to bolster his legitimacy, Maduro continues to hold elections significantly stripped of their democratic requirements. In the 2020 parliamentary elections, the Guaidó-led faction of the opposition refused to participate due to serious electoral irregularities. The electoral system has been re-designed in favour of the government. In June 2020, the Supreme Court stripped three of the four main opposition parties of their leadership, allowing the parties to be co-opted by pro-government politicians. Along with an expanding of the National Assembly, from 167 to 277 seats, this severely weakened the opposition. The Maduro administration also refused to allow international electoral observers.

With low voter participation, the president and his left-wing allies won 257 of the 277 seats in the assembly, taking 67.7 percent of the vote. Regardless of civilian disenchantment with politics, solidified his grip on the last democratically elected institution in Venezuela.

\section{Another Populist Playbook: Foreign Plots}

Maduro has another similarity with other populist leaders: he feeds fears of external plots to distract the public's attention from daily problems inside the country. From the outset of his reign, conspiracy theories have been central to Maduro's discourse (Carey, 2019). Shortly after he took office, Maduro accused foes of plotting to assassinate him and claimed that "imperialist" enemies infected Chávez with cancer (Reuters, 2013). The Venezuelan government has trumpeted the conspiracies as a way of rallying its supporters around a shared, unsubstantiated enemy. Both Chávez and Maduro used conspiracies as a weapon to discredit or demonize adversaries and to generate a fortress mentality among supporters (Piñeiro, Rhodes-Purdy and Rosenblatt, 2016).

Unable to control the collapse of the economy and chronic issues inside the country, Maduro sustained typical Chávezstyle conspiracy theories and claimed foreign states were the main culprit of the country's problems.In 2016, Maduro announced a plot orchestrated by the US and its alleged domestic conspirators to sabotage the Venezuelan economy. Two weeks later, he announced that the US Embassy, with the participation of opposition leaders, carried out a cyberattack against the banking system (Telesur English, 2016).He also explicitly attributed the country's socio-economic misery to "external dynamics" by constantly invoking the "economic war" waged against his government by internal and external enemies (Reuters, 2018). Maduro has also constantly characterized the widespread protests and rallies as attempted coups fostered by the United States against his government. For Maduro, there was an international right-wing conspiracy working with the radical opposition inside the country to oust him.

Meanwhile, the US's increasingly aggressive policy towards Venezuela helped Maduro paint himself as the victim of a foreign plot by the US in an effort to gain favour at home and abroad. First, the Obama administration declared Venezuela as an "an unusual and extraordinary threat to national security" and imposed sanctions on a few high-ranking government officials in 2015 (Neuman, 2015). Then, the Trump administration further increased the pressure by adopting a "maximum pressure" policy to topple Maduro and pave the way for a democratic transition inside the country. Washington imposed another set of sanctions against Venezuela in 2019 in a bid to oust Maduro. The PDVSA state-led oil company was barred from accessing US financial markets as of 2017 and from selling oil to any US-related individual or corporation as of 2019.

These sanctions disrupted he flow of petrodollars. But the aggressive policies also provided Maduro with a tailor-made excuse: he could blame the crisis on external powers and establish more sweeping 
government control over key government institutions (Dempsey, 2018). Similarly, Maduro used the sanctions to shore up his domestic supporters and loyalists. Maduro shouted to a large crowd: "I invite the entire Venezuelan people, in all the states and regions of the country, to join in. No one messes with our country. The Yankee boot will never touch it," (New York Times, 2015).

Being in dire need of economic and financial relief, the Maduro government managed to find ways of evading sanctions by deepening its alliances with like-minded regimes. In response to rising isolation in the region, the Maduro administration has become more reliant on alliances with Iran, Turkey, China, Russia, and other autocratic populist international actors. 


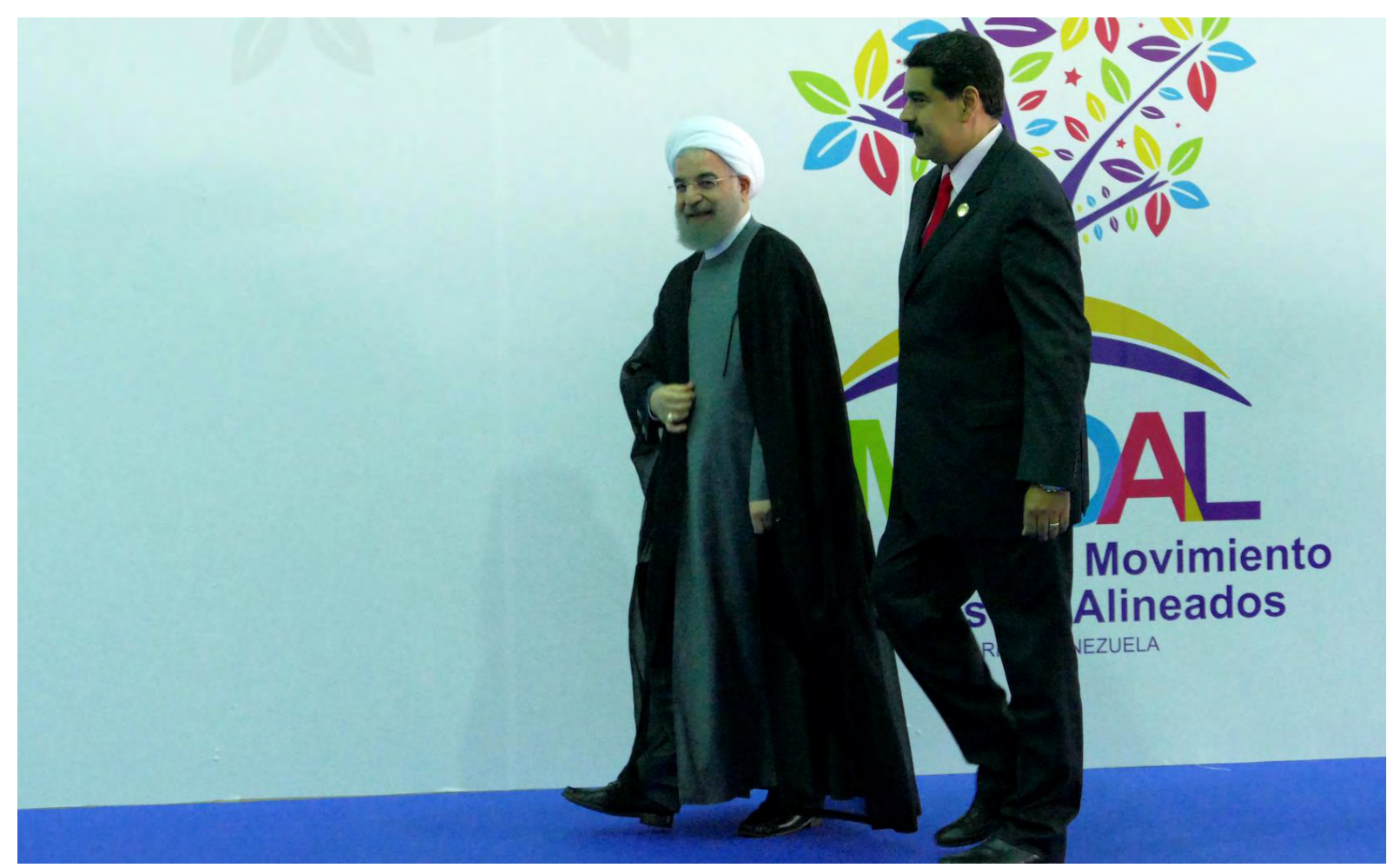

Iranian President Hasan Rouhani and Venezuelan President Nicolas Maduro at the opening ceremony of the NonAligned Movement Summit in Porlamar, Venezuela on September 17, 2016

\section{An Authoritarian Coalition with Like-minded Regimes}

Maduro's less favourable conditions after Chávez were not limited to domestic dynamics. Venezuela's position has significantly changed in the regional and international context since Maduro assumed the presidency. In the late 1990s and early 2000s, Latin America experienced a "Pink Tide," as a wave of leftist governments took power in the region. While this surge, which began with Chávez's election in Venezuela in 1998, created a favourable environment for Chávez, it had begun and continues - to recede as right-wing parties once again gained power in the region.

With the demise of potential left-wing allies, Maduro's government has become increasingly isolated in the Western Hemisphere. Rising repression, human rights violations, economic crisis, and widespread corruption cases have all accelerated the regime's regional isolation.

The changing price of raw materials has also altered regional dynamics (Rome- ro and Mijares, 2016). In 2005, Chávez launched PetroCaribe, which provided a stable oil flow to many Caribbean and Central American nations on preferential payment terms. When Venezuela's oil production plunged and the US sanctions ramped up, the Maduro administration scaled back the program. In return, Venezuela lost the diplomatic support of those small countries, which had until then that blocked nearly every resolution put forward by other member states condemning or pressuring the Maduro government.

Venezuela's isolation in the regional context has become more visible in the initiatives led by the Organization of American States (OAS), which is an influential regional organization that includes 35 independent countries in the Western Hemisphere. The OAS has become the principal body through which the countries in Latin America have exerted pressure on the Maduro administration as instability intensified in the country. The 
Secretary General of the OAS, Luis Almagro, called the Inter-American Democratic Charter in May 2016, a process that could lead to Venezuela's suspension from the organization. The Maduro government formally withdrew from the regional body in April 2019 (Gallón, 2019)

More external pressure and increased isolation in the region further destabilized the economy and the state's income. Being in dire need of economic and financial relief, the Maduro government managed to find ways of evading sanctions by deepening its alliances with like-minded regimes. In response to rising isolation in the region, the Maduro administration has become more reliant on alliances with China, Russia, and other autocratic populist international actors. Strong ties with China and Russia have strengthened the resilience of the Maduro administration. During the Chávez era, these bilateral relations blossomed due in large part to the close personal relations between presidents. These two revisionist powers have been eager to trade their financial and diplomatic support to Venezuela as part of their geopolitical intentions in America's backyard. With that intention, Moscow and Beijing have played a crucial role in keeping the Venezuelan regime afloat, primarily through loans and other contributions (Rouvinski, 2019).

Several other countries also appeared eager to cooperate with the Venezuelan government despite the risk of more sanctions. These countries have become vital partners, filling the void at a time when many Western companies express reluctance to engage in business with Venezuela for fear of incurring US sanctions. A widening array of friendly countries seemed to expect preferential access to Venezuela's market and to cultivate lucrative commercial relationships. Erdogan's Turkey is one of the opportunistic new "allies" that has extended a lifeline to Maduro (Oner, 2020).

Meanwhile, Cuba still remains an influential actor in Venezuela. Cuban security officials are reportedly involved in various key areas of the administration, including intelligence services. Maduro's connection to Cuba, cultivated when he was a young man, has made Havana more pervasive during his rule (Naim and Toro, 2018). It is believed that Cuban security training and technical assistance has significantly helped the Maduro government to establish a firewall against internal and external threats (Fonseca and Polga-Hecimovich, 2020). In return for this aid, the Maduro administration provided significant oil support to Cuba. While Cuban military and intelligence personnel help Maduro stay in power, the oil provided by Venezuela continues to provide much-needed support to the Cuban economy. 


\section{CONCLUSION}

The last seven years under Maduro have been marked by rising polarization, election irregularities, looming economic crisis, and massive protests. Maduro's incompetent policies have further propelled the country into a downward spiral, which eventually forced more than five million people to leave the country. The same political, economic, and social shocks contributed to the regime's rising authoritarianism. As the opposition gained popular support through the elections and external pressure on Maduro grew, the resorted to anti-democratic means to maintain his grip on power.

There is a widespread consensus that Maduro is an unpopular leader. Despite his lack of popular support, Maduro still shares particular features with other populist leaders. His discourse and political style - framing politics as constant battle between the good and corrupt - is notably populist in nature. Similarly, his struggle for power at the expense of rising repression and restrictions is in line with the autocratic practices of other populist leaders. As several scholars argue, Maduro has transformed an inherited, semi-authoritarian regime into a full-blown authoritarian one (Corrales 2020; Marsteintredet, 2020).

Lacking personal charisma and booming oil revenues, Maduro has struggled to obtain his predecessor's popular support and failed to legitimize his rule at the polls. Instead, Maduro consolidated his power through sharing it with elites and the military. Externally, the country's social, economic, and political environment has contributed to the growing perception among international actors that the regime is becoming ever more authoritarian and unstable. In the face of the greatest threat to its survival both at home and abroad, Maduro and his allies eliminated Venezuela's remaining democratic institutions.

The Maduro administration remains reluctant to make any concessions that might erode its power. With implicit and explicit power-sharing arrangements with key actors at the domestic level, Maduro has been able to cling to power. Currently, the military still supports Maduro; there are no signs this will change anytime soon. As the recent political events suggest, and barring free and fair elections, unpopular populist Maduro will remain in power. 


\section{REFERENCES}

. (2008). "Chávez Insiste En Que Gobernará Hasta 2021." La Tercera. Feb. 19, 2008. www.latercera.com/noticia/chavez-insiste-en-que-gobernara-hasta-2021/ (accessed on December 14, 2020).

. (2013). "Who Is Nicolás Maduro? Profile of Venezuela's New President." The Guardian. April 15, 2013. www.theguardian.com/world/2013/apr/15/nicolas-maduro-profile-venezuela-president (accessed on December 14, 2020).

. (2014). "Venezuela President Approval Rating Drops to 24.5 Percent in November: Poll." Reuters. Dec. 2, 2014. www.reuters.com/article/us-venezuela-politics/venezuela-president-approval-rating-drops-to-24-5-percent-in-november-poll-idUSKCNOJG29T20141202 (accessed on January 27, 2021).

(2015). "Venezuela Election: Opposition Coalition Secures 'Supermajority'." The Guardian. Dec. 9, 2015. https://www.theguardian.com/world/2015/dec/09/venezuela-election-opposition-coalition-secures-supermajority (accessed on January 27, 2021).

-. (2017). "The Supreme Court of Justice of Venezuela: an Instrument of the Executive Branch." International Commission of Jurists (IJC). August 2017.

. (2018). “Venezuela's Maduro Says Will Win in 'Economic War' Post-Election." Reuters. Thomson Reuters. May 9, 2018. www.reuters.com/article/us-venezuela-election/venezuelas-maduro-says-will-win-in-economic-war-post-election-idUSKBN1IA3KM (accessed on January 27, 2021).

. (2020). "Report of the Independent International Fact-Finding Mission on the Bolivarian Republic of Venezuela." UN Human Rights Council, 45th Session. September 14-October 2, 2020.

. (2020). "Venezuela: What Lies Ahead after Election Clinches Maduro's Clean Sweep."

International Crisis Group. Dec. 22, 2020. www.crisisgroup.org/latin-america-caribbean/andes/venezuela/85-venezuela-what-lies-ahead-after-election-clinches-maduros-clean-sweep (accessed on January 27, 2021).

(2020). "Venezuela Pardons Dozens of Opposition Politicians as Election Nears." Reuters. Thomson Reuters, 31 Aug. 2020, www.reuters.com/article/us-venezuela-politics/ venezuela-pardons-dozens-of-opposition-politicians-as-election-nears-idUSKBN25R2LQ (accessed on January 27, 2021).

—. (2020). "Venezuela: Rulings Threaten Free and Fair Elections." Human Rights Watch. July 7, 2020. https://www.hrw.org/news/2020/07/07/venezuela-rulings-threaten-free-and-fair-elections\# (accessed on January 27, 2021).

Alarcón, B., Álvarez, A., \& Hidalgo, M. (2016). "Can democracy win in Venezuela?" Journal of Democracy. 27(2), 20-34.

Alarcón Deza, Benigno (ed). (2014). El desafío venezolano: continuidad revolucionaria o transición democrática.Caracas: UCAB.

Angosto-Ferrández, Luis Fernando. (2016). "The afterlives of Hugo Chávez as political symbol." Anthropology Today. 32(5), 8-12.

Bull, B., \& Rosales, A. (2020). "The crisis in Venezuela: Drivers, transitions, and pathways." European Review of Latin American and Caribbean Studies. 
Cannon, B., \& Brown, J. (2017). "Venezuela 2016: the year of living dangerously." Revista de Ciencia Política. 37(2), 613-633.

Carey, J. M. (2019). "Who Believes in Conspiracy Theories in Venezuela?" Latin American Research Review. 54(2), 444-457. DOI: http://doi.org/10.25222/larr.88

Chuck, Elizabeth. (2017). "Nicolas Maduro: The Path from Bus Driver to Venezuelan President." NBC News. August 2, 2017, www.nbcnews.com/storyline/venezuela-crisis/nicolas-maduro-path-bus-driver-venezuelan-president-n788121 (accessed on January 27, 2021).

Cola, Julian R. (2018). "Venezuela Elections: Who Is Nicolas Maduro?" TeleSUR English. May 10, 2018. www.telesurenglish.net/analysis/Who-is-Nicolas-Maduro-20180510-0014.html (accessed on January 27, 2021).

Corrales, Javier, and Penfold, Michael. (2011). Dragon in the Tropics: Hugo Chávez and the Political Economy of Revolution in Venezuela. Washington, DC: Brookings Institution Press.

Corrales, Javier; von Bergen, Franz. (2016). "Coup Nouvelle: Did We Just Witness a New Type of Coup in Venezuela?" Global Americans. July 15, 2016. https://theglobalamericans. org/2016/07/coup-nouvelle-just-witness-coup-venezuela/ (accessed on January 27, 2021).

Corrales Javier and Diego Recinos. (2016). "After Brazil, Will Venezuela Be Next to Remove Its President?" Americas Quarterly. May 12, 2016. www.americasquarterly.org/article/after-brazil-will-venezuela-be-next-to-remove-its-president/ (accessed on January 27, 2021).

Corrales, Javier. (2016). "Venezuela’s Odd Transition to Dictatorship." Americas Quarterly. October 24, 2016. www.americasquarterly.org/article/venezuelas-odd-transition-to-dictatorship/ (accessed on January 27, 2021).

Corrales, Javier. (2016). "Venezuela: Is This the Final Straw?” Americas Quarterly. June 13, 2016. https://www.americasquarterly.org/article/venezuela-is-this-the-final-straw/ (accessed on January 27, 2021).

Dempsey, Michael. (2018). “Takeaways from Venezuela's Long Descent.” War on the Rocks. September 5, 2018. https://warontherocks.com/2018/08/takeaways-from-venezuelas-long-descent/ (accessed on January 27, 2021). De la Torre, C. (2017). "Populism in Latin America." The Oxford handbook of populism.

Dobson, Paul. (2019). “Venezuelan Presidential Candidate Profile \#4: Nicolas Maduro.” Venezuelan Analysis. Aug. 1, 2019. https://venezuelanalysis.com/analysis/13824 (accessed on January 27, 2021).

Ellsworth, Brian. (2016). "For Economy Czar of Crisis-Hit Venezuela, Inflation 'Does Not Exist." Reuters. Jan. 7, 2016. www.reuters.com/article/us-venezuela-economy/for-economy-czar-of-crisis-hit-venezuela-inflation-does-not-exist-idUSKBN0UL27820160107 (accessed on January 27, 2021).

Fonseca, Brian, and John Polga-Hecimovich. (2020). “Two Nations, One Revolution: The Evolution of Contemporary CubaVenezuela Relations." Wilson Center Latin America Program.

Freeman, Will. (2020). "Why Maduro Is Relying on Courts to Silence Dissent More than Ever Before." Global Americans. July 23, 2020. https://theglobalamericans.org/2020/07/under-mad- 


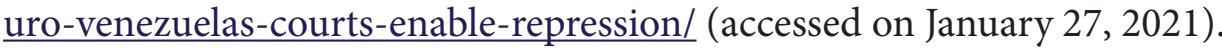

Gan, N. (2020). "Rule of law crisis of rule, militarization of citizen security, and human rights in Venezuela." European Review of Latin American and Caribbean Studies. 109, 67-86. http:// doi.org/10.32992/erlacs.10577

Gallón, Natalie C. (2019). Venezuela says it will split from OAS as unrest continues. CNN. https://www.cnn.com/2017/04/27/americas/venezuela-leaving-oas/index.html (accessed on February 2, 2021)

García-Guadilla MP, Mallen A. (2019). "Polarization, Participatory Democracy, and Democratic Erosion in Venezuela's Twenty-First Century Socialism." The ANNALS of the American Academy of Political and Social Science. 681(1):62-77.

Naim M, Toro F. (2018). “Venezuela’s Suicide: Lessons From a Failed State." Foreign Affairs. 97(6):126-138. https://www.foreignaffairs.com/articles/south-america/2018-10-15/venezuelas-suicide (accessed on January 27, 2021).

Neuman, William. (2015). “Obama Hands Venezuelan Leader a Cause to Stir Support." The New York Times. March 11, 2015. www.nytimes.com/2015/03/12/world/americas/venezuela-nicolas-maduro-obama.html (accessed on January 27, 2021).

Oropeza Valentina. (2013). “El ‘Delfín’ Que Conducirá La Revolución Bolivariana.” El Tiempo. Apr. 15, 2013. www.eltiempo.com/archivo/documento/CMS-12742462 (accessed on January 27, 2021).

Kenny, P.; Hawkins, K.; Ruth, S. (2016). "Populist Leaders Undermine Democracy in these 4 Ways. Would a President Trump?” Monkey Cage. August 18, 2016. https://www. washingtonpost.com/news/monkey-cage/wp/2016/08/18/populists-undermine-democracy-in-these-4-ways-would-president-trump/?utm term=.92dcafd86909 (accessed on December 14, 2020).

Krygier Rachelle, Anthony Faiola. (2020). "Venezuela’s Last Democratic Institution Falls as Maduro Attempts De Facto Takeover of National Assembly." The Washington Post. Jan. 6, 2020. www.washingtonpost.com/world/the americas/venezuelas-last-democratic-institution-falls-as-maduro-stages-de-facto-takeover-of-national-assembly 12020/01/05/8ba496fe-2d8f-11ea-bffe-020c88b3f120 story.html (accessed on January 27, 2021).

Levitsky, Steven and Loxton, James. (2012). "Populism and Competitive Authoritarianism in the Latin America." Paper for 108th Annual Meeting, American Political Science Association, New Orleans, August 30, 2012.

Marsteintredet, L. (2020). "With the cards stacked against you. Challenges to a negotiated transition to democracy in Venezuela." European Review of Latin American and Caribbean Studies. Maya, M. L. (2018). "Populism, 21st-century socialism and corruption in Venezuela." Thesis Eleven, 149(1), 67-83.

Mueller, Jan-Werner. (2013). "Populism Without the People by Jan-Werner Mueller." Project Syndicate. Apr. 17, 2013. www.project-syndicate.org/commentary/nicolas-maduro-and-the-essence-of-populism-by-jan-werner-mueller?barrier=accesspaylog (accessed on January 27, 2021). 
Neuman, William. (2015). "Venezuelan Opposition Claims a Rare Victory: A Legislative Majority." The New York Times. Dec. 7,

2015. www.nytimes.com/2015/12/07/world/americas/venezuela-elections.html (accessed on January 27, 2021).

Oner, Imdat. (2020). “Turkey and Venezuela: An alliance of convenience.” Woodrow Wilson Center Latin America Program. Washington DC.

Oropeza, Valentina. (2013). “El ‘Delfín’ Que Conducirá La Revolución Bolivariana.” El Tiempo. Apr. 15, 2013. www.eltiempo.com/archivo/documento/CMS-12742462 (accessed on January 27, 2021). Penfold, Michael. (2018). "Food, Technology, and Authoritarianism in Venezuela’s Elections." Woodrow Wilson Center.April 18, 2018.

Piñeiro, Rafael; Rhodes-Purdy, Matthew and Rosenblatt, Fernando. (2016). “The Engagement Curve: Populism and Political Engagement in Latin America." Latin American Research Review. 51 (4): 3-23. DOI: https://doi.org/10.1353/lar.2016.0046

Rodriguez, Felix Seijas. (2017). “Venezuela: The Brutal Truth About Maduro's Election Victory.” Americas Quarterly. October 19, 2017. https://www.americasquarterly.org/article/venezuela-the-brutal-truth-about-maduros-election-victory/ (accessed on January 27, 2021).

Rodriguez-Garavito, C. \& Gomez, K. (2018). "Responding to the Populist Challenge: A New Playbook for the Human Rights Field.” In: C. Rodriguez-Garavito, K. Gomez (eds.), 2018, Rising to the Populist Challenge: A New Playbook for Human Rights Actors. 11-44. Bogota: Dejusticia.

Romero, C. A., \& Mijares, V. M. (2016). "From Chávez to Maduro: Continuity and change in Venezuelan foreign policy." Contexto internacional. 38(1), 165-201.

Romo, Rafael and Brocchetto, Marilia. (2017). "Venezuela Protests: What You Need to Know." CNN. Apr. 20, 2017. www.cnn.com/2017/04/18/americas/venezuela-protest-explainer/index. html (accessed on January 27, 2021).

Rouvinski, Vladimir. (2019). "Russian-Venezuelan Relations at A Crossroads.” Woodrow Wilson International Center for Scholars, Latin American Program. https://www.wilsoncenter.org/ publication/russian-venezuelan-relations-crossroads (accessed on January 27, 2021).

Smilde, D. (2015). “The End of Chavismo?” Current History. 114(769), 49-55.

Smilde, D. (2016). "With Blacklisted Officials, Venezuela's Maduro Builds a Core.” WOLA. August 5, 2016. https://venezuelablog.org/with-blacklisted-officials-venezuelas-maduro (accessed on January 27, 2021).

Strønen, Iselin Åsedotter. (2016). “A Civil-Military Alliance: The Venezuelan Armed Forces before and during the Chavez-Era." CMI Working Paper Series. 2016:4

Semple, Kirk. (2017). "Venezuela's Two Legislatures Duel, but Only One Has Ammunition." The New York Times. Nov. 3, 2017. www.nytimes.com/2017/11/03/world/americas/venezuela-national-assembly-maduro.html (accessed on January 27, 2021).

Weyland, K. (2013). "Latin America's Authoritarian Drift: The Threat from the Populist Left." Journal of Democracy. (3), 18-32. 


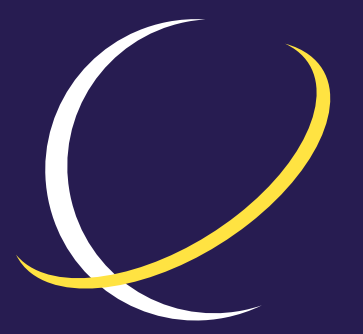

\section{ECPS \\ EUROPEAN CENTER for POPULISM STUDIES}

\section{ABOUT ECPS}

The European Center for Populism Studies (ECPS) is an independent, nonpartisan, nonprofit organization, based in Brussels, for research on and analysis of challenges posed by the resurgence of political populism. ECPS facilitates collaboration among networks of academic experts, practitioners, policymakers, media, and other stakeholders. ECPS offers a platform for the exchange of policy solutions on issues relating to rising populism and provides insights for policy-making and critical analysis to raise broader awareness and engagement through:

\section{Publications}

\section{Academic publications}

Policy reports

White papers

Commentaries

Podcasts and interviews with experts

Events, seminars, workshops, and conferences

\section{Research Programs}

Authoritarianism

Digital Populism

Economics

Environment \& Climate

Extremism \& Radicalisation

\section{Gender}

Human Rights

Foreign Policy

Leadership \& Persona

Migration

\section{ECPS Youth Program}

ECPS Academy 